\title{
Self-Respect in School
}

\author{
Vera Lucia Trevisan de Souza, ${ }^{1, *}$, Vera Maria Nigro de Souza Placco
}

\author{
${ }^{1}$ Graduate Program in Psychology from the Catholic University of Campinas (PUC-Camp), Campinas, 13060-904, Brazil \\ ${ }^{2}$ Graduate Study Program in Psychology of Education from the Catholic University of São Paulo (PUC-SP), São Paulo, 05014-901, \\ Brazil
}

\begin{abstract}
This study aims to identify the values found in school and to verify which interactions favor the construction and/or maintenance of moral values, especially self-respect. Departing from the theoretical approach of Socio-historical Psychology, the investigation is based on the studies on morality conducted by Jean Piaget and Yves de la Taille. The study was conducted over two years in a 1st grade public school, with groups of teachers and students, as well as educational coordinator. We used classroom and school meetings observations, that were taped and transcribed. Content analysis was the methodological approach used. Some conclusions are that interactions promoting and not promoting the construction of moral values coexist in school, the second being the most frequent.
\end{abstract}

Keywords Education, Moral Values, Moral Education, Authority

\section{Introduction}

Our purpose in this study was to identify values ${ }^{1}$ present at school and verify which interactions promote their construction and/or maintenance, and, in case of self-respect, the moral values. Besides the complaint of educators and facts that we have been noticing, the question of respect at school has been a subject matter of discussions at the media, has been leading parents and children to therapist offices and has been mobilizing many researches in Brazil and abroad.

"Disrespect" - such as it is called by educators - could be observed on several occasions during this research inside the school, expressed by conducts that are inappropriate to the situation, and from then on, we started asking ourselves: if lack of respect is a fact, mainly in the classroom, what is the origin of it? To what extent do interactions between teachers and students, students and students, teachers and coordinator favor or not the construction of self-respect?

Our hypothesis was that if disrespect exists and persists at school it is because the interactions somehow favor its maintenance.

La Taille[7], when studying the genesis of the feeling of shame, defines "I" as the "set of self representations." These representations that grant the being an identity are always value representations. These values that form the identity may be moral - when associated with justice, loyalty, honesty and other moral virtues, and non-moral - when associated with beauty, professional success, wealth, etc.

* Corresponding author:

vera.trevisan@uol.com.br (Vera Lucia Trevisan de Souza)

Published online at http://journal.sapub.org/edu

Copyright (C) 2012 Scientific \& Academic Publishing. All Rights Reserved
Non-moral values generate self-esteem, while moral values generate self-respect. Thus, the feeling of self-respect is generated and supported by moral values and, at the same time, incorporates them.

In fact, the author understands self-respect as "positive self representations, which include moral values". [4] It is the synonym of "honor-virtue", which would be equivalent to dignity. Therefore, self-respect would be a condition to morally respect another person, that is, if you do not respect yourself, you do not respect the other, which grants self-respect a non-dissociable nature as regards respect to the other.

In order to examine interactions that would reveal the presence of self-respect, we focused on the set of data collected in the research through observations and tape recording, which we transformed in "scenes" aimed at placing the context where the facts developed. We selected interactions that we deemed would represent situations involving respect. Then, we asked the question: which do favor and which do not favor the construction/maintenance of self-respect? And a new selection was made. Departing from it, we asked ourselves which contents had interactions that did and did not promote the construction/maintenance of self-respect. These are the interactions we have based ourselves on to review data with a view to outlining questions involving self-respect in school.

\section{Method}

In this paper, we sorted out from the scenes those interactions that both promote and do not promote the construction/maintenance of self-respect. First, we will refer to promoting interactions, where the following contents 
emerge: investment in/from the other, a priori belief in the capacity, acceptance and care and the facing of conflicts.

\section{Results and Discussion}

\subsection{Interactions that Promote Construction and Maintenance of Self-Respect}

\subsubsection{Investment in the Other}

At a meeting with Helena (school coordinator), she talks about the Pedagogic Work Hours - HTPCs ("Horas de Trabalho Pedagógico"). She is frustrated for not having been able to continue to read and discuss the texts about learning with the teachers. "It's useless, the morning group doesn't read, doesn't get involved with the study at all. The afternoon group is better - at least they read, discuss - certainly not how I would like them to, but we managed to move forward. But with the morning group we didn't. She is also upset because she thinks that the teachers do not even know which story books they have in classroom, they do not encourage students to read and continue not to use the newspapers. She believes that in this way students will certainly not improve their reading, because most activities used by the teachers involve copying from the blackboard.

At the next meeting with Helena, she says that the strategy thought to engage the group in reflection did not work: "I was outraged with the attitude of one of the teachers. She discredited me in front of the group." She says she has read the text she had chosen for understanding it signaled the possibility of facing the students' learning difficulties inside the school walls. Prior to the reading, she told the group she recognized the difficulty of the work, the slowness of results, but she was sure it was within the professional possibilities of the school team.

After the joint reading, Helena asked the teachers what they thought. A teacher of the afternoon period resented and said: "It's always like that; here it's saying that it is the teacher's fault. We are always guilty, but no one comes here to see how we work, who our students are. Children do not respect because there is no one in this school imposing respect, no one does anything. Besides, these HTPC meetings are very boring; at the other school it's wonderful; the coordinator only suggests the activities and we do them if we want to. Here we are required to do them." Helena stated that at this moment she got speechless: "I flushed with anger and, fearing I would lose my temper, I didn't manage to say anything else. I felt alone, powerless. Some teachers agreed with the teacher by nodding their heads. I took a deep breath, said that this was not what I thought and the meeting ended."

Worst of all, according to Helena, is that the evaluation that the Teaching Board requested about the reading project how teachers work the reading with children - had a very detailed questionnaire that the teachers answered. According to the answers, the work is excellent. Then Helena had to produce a single report for the Board, based on the teachers' answers. Result: The report forwarded to the Board reveals an excellent reading work, which Helena does not agree with. She states that the teachers didn't tell the truth in the answers to the questionnaire: "Why? Are they aware that they are lying? Or do they really think they do what they wrote?" In the assessment she did on the parallel remedial work, teachers say they do not see much result in the remedial project, pointing out many problems and naming students who didn't make any progress "at all", without making any movement of reflection on the causes for the poor results. The assessment was forwarded in writing and some wrote that the students are very lazy.

There is something we have identified in the coordinator along the scenes that seems characteristic of the feeling of self-respect. This "something" mobilizes her conduct as respects the work with teachers. We call this characteristic "Investment in the other" for the belief, a priori, in the other's capacity. It seems that this is the ingredient that mobilizes Helena to continue investing in the work with teachers, although she has many reasons to give up.

But, what would this conduct have to do with self-respect, understood as "the set of positive self representations that contemplate moral values"?[5]

Our answer starts with two other questions: where does it come from and/or what explains the motivation for Helena's acting and thinking? And what is moral in this motivation, since self-respect belongs to the moral order?

Helena has a belief, a priori, in the capability of students to learn and thinks that it will be the change in the teachers' work that will provide a better performance from students. Resulting from this belief, there is another one - in the capability of teachers of changing their way of seeing the students, changing their practice. This belief causes Helena to constantly change her practice by developing new conducts to trigger reflection of the group of teachers. This shows that she has an image of herself as capable of doing this job, although she is sometimes discouraged, to the point of doubting of this capability. This characteristic of Helena's character, of investing and believing in the capability of others, is only justified because she invests and believes in herself and in her capacity of doing a good job. Thus, offering a quality teaching to the school students, through a better work of the teachers, is seen by Helena as a duty; and achieving this purpose is a way of ensuring the children's right to quality teaching. These are the first components of moral we underlined, which would be in agreement with the affirmation that ".. only what grants rights and duties in interpersonal relationships is moral".[7]

Thus, we may say that ensuring the students' right to quality teaching is a value that would be in the core of representations that Helena has about herself, a fact that is evident every time she faces "something" strange to such value, as revealed in the speech about teacher Dolores:

The uneasiness towards her is significant, because I gave her the texts distributed at the HTPCs she didn't attend and I hear: don't give this to me now because I'm leaving![...] she continues at school[...] refusing to take responsibility for tasks she is in charge of[...] I gave up on her, I will no longer 
insist, because I can't stand it anymore! She says such things in front of other teachers and demoralizes me; I can't figure out what to do.

Taking responsibility for tasks you are in charge of means, from Helena's point of view, ensuring the students' right to learning. The loss of temper experienced by Helena in the scene described above could be interpreted as a feeling of shame? The feeling of shame can be moral or non-moral. However, since here we are addressing self-respect, this is a case of moral shame ${ }^{4}$.[5]

The moral shame would result from the feeling of self-respect itself, being equivalent to a negative judgment of your own image (or pre-judgment) exactly because the value generating the negative judgment would be integrated to the "I". But, based on this definition, could we say that Helena's uneasiness corresponds to the feeling of moral shame?

Harkot-de-La-Taille[4], in his "Ensaio semiótico sobre a vergonha" states that there are two primary conditions for experiencing the feeling of shame: exposure before others and inferiority. There is shame only when inferiority and exposure combine. In the act we described, there is a clear attempt of the teacher to undermine Helena in front of the group of teachers, attempt felt by Helena, when she says: "I was outraged... she discredited me." Thus, exposure and inferiority are present.

It is not enough to be negatively judged to feel shame, it is necessary that the judged person legitimizes his judges, believes that they share the same values as he does and also agrees with the judgment, that is, shame is the result of a negative self-judgment - retrospective shame.[7]

The judges are the teachers of her group, instance where Helena exercises her role of authority, of educator; thus, they are legitimate. Participating in activities, reading texts, attending meetings correspond to values that are shared, either by the entire group or, still, with the same purposes, by part of the group. Thus, it is possible to say that what Helena feels is retrospective shame, that is, shame resulting from the depreciation of her "good" image.

During the scenes, we noticed in Helena's attitudes the presence of prospective shame which corresponds to your own self-respect, since the fear of feeling shame is one of the basic motivations for the moral thinking and acting. That occurs because the worthy person, that is, one who has dignity as a core value in the representation of himself, looks after preserving his self-respect, which he values. Such self-respect is made of ideals that the person tries to achieve, a search that is a motivation.

We said that Helena, protagonist of these scenes, considers respect - for herself and for the other - her core value and that, in her way of being, she tries to preserve this value. This search occurs in and through the interaction with others - judges of her actions/conducts -, only ones capable of ratifying her self-respect by respecting her. Such considerations allow saying that Helena respects people with whom she interacts and demands equal respect from them. It is based on this value that she tries to act, even becoming anguished by the little result she achieves or by the teachers' resistance.

Helena proposes to read the text in group and, before doing so, she makes considerations on the difficulty of facing the problems at school, recognizing the challenges, the anguish for the delay in obtaining results, and further explains her belief in the capacity of the group. That is, Helena tries to grant positive value to the teachers' own image. This movement can also be interpreted as a form of presentation that is based on establishing common references, which should make it possible to start the dialogue. It does also express respect for others, insofar it recognizes their difficulties and possibilities. However, even this care and respect did not ensure completion of the activity - one of the teachers reacts to the contents of the text, taking the position of victim and the group gets quiet, legitimizing the speech of that teacher, who does also attack Helena's image as school representative ("who doesn't do anything") and organizer and leader of the permanent education process, HTPCs ("which are very boring"). She also accuses her of being authoritarian - "at the other school, the coordinator does only suggest; here we are required to do." If "not doing anything for the respect" and the "boredom" of meetings is not shared by Helena as a value because she knows what she does and why she does it, the accusation of authoritarian seems to touch her. In her depositions, in many scenes, Helena reveals that she lives in permanent conflict between ordering and seeming authoritarian, but complying with her duty, and "letting things follow their course", seeming "nice" and not complying with her duty. This is what seems to make her get speechless, flushing, feeling shame. The teacher exposes her in front of the group - the judges -, undermining her in relation to values she shares.

Then, Helena confesses she is tired, and even the researcher's welcome and her words of encouragement do not seem to work. That's because there is no social antidote against shame - the ashamed person wishes to isolate. Only time and context will make it possible for him to overcome it.

When self-respect is hurt could we, from the standpoint of interaction, envision a certain dissemination of the injury? That is, could the loss of part of the self-respect and the feeling of shame cause the person to see others around him as disrespectful, and the ordinary day-to-day conducts start to assume another dimension? Since Helena is still discouraged and sees, more and more, the difficulties, the absences, and there seems to be nothing exciting at school: "no one does anything, no one knows anything..." would she have assumed as value the judgment of the teacher that referred to indiscipline? And also her "incompetence" assessed by the same teacher and legitimized by the group: “... that's what I forwarded in April and nothing happened..."?

The fact is that Helena lives an identity dilemma - she must either resume her purposes with effort and preserve her self-respect (ideal of ego) or give in to the adversities of the context, let go to the mechanical doing and change her self-concept (ego). 
It happens that her indignation with the attitude of the teachers remains, either as regards their work with the students or the answers to the questions of the Teaching Board. She perceives the inconsistencies between what is done and what is written, is worried about the evaluation the school may be assigned by the Teaching Board, does not agree with the fact that teachers blame the students for not learning and does not know what to do. However, Helena fears to submit the report to the group and to point out the inconsistencies - would it be fear of feeling shame? There is still, in Helena's saying, something that "makes the situation worse" - the act of discriminating students considering them "incapable", the indifference of some teachers with respect to the problem and the categorization of students as "lazy" this was too much! Thus, she could not act, under penalty of feeling prospective shame, because her duty forced her to ensure the rights of students. "The duty is a stronger type of want than others"[5] and it seems to us that this want mobilizes Helena to resume the discussion of the question in the group.

We are in early December 2001 and I find Helena so excited that she immediately starts telling that the board meeting was a success. She prepared the agenda in advance, took a text about attitudes and asked: where does the students' lack of limits come from? Which would be the ways out for dealing with attitudes that bothered teachers so much? Helena kept writing the answers on the blackboard. The group, for the first time, did a collective reflection on the subject, and proposed alternatives, such as: engaging the family in discussions about the subject, creating an individual file for each student and follow up the process, trying to identify their difficulties. While no indications appeared, in an explicit manner, of the need of changing actions of teachers in class, as Helena expected, she considered that there was and advance in the awareness of teachers that this was a serious problem that should involve the participation of everyone in school.

All teachers agreed to start the next year setting forth coexistence rules: starting from the conversation round with students, they would prepare common rules and set up posters that would be permanently displayed on the classroom's mural, and would be rethought and redone over the year. They also discussed the importance of everyone feeling co-responsible for the learning of all school students.

The theme discipline had caused, throughout the year, movements of complaints of teachers who always considered the lack of discipline the reason for the school problems, either for their tiredness, lack of control or impossibility of conducting a better class. However, at this meeting, the discussion flows and reflection happens. Why?

The topics "starting from what teachers think", "respect to what they think", and mainly the propositions that should be formulated by them are present in the interaction. We could say that we invest in their good, best characteristics - their knowledge and experiences - and that is "offering them" self-respect. The common background here seems to concern the value granted to the question: "everyone should feel co-responsible for the learning of all school students", thus broadening the role of teachers - they are not responsible for their students only, but for all of them. Does a new (ethical) value linked to identity appear here?

Even the path to start on seems proper - "preparing common rules with students", revealing a concern with moral education, such as it should occur at school: starting from rules that everyone in the community may share as value and keep discussing, on a daily basis, in the relationship with the attitudes of children. Would teachers have appropriated the form of presentation that aims at creating common backgrounds developed by Helena at the meetings? If yes, then we confirm our hypothesis, i.e., it is by the interaction based on common values that new values are built, when a space is provided, where subjectivities in relationship transcend their private worlds, compare beliefs and values and share, or $\operatorname{not}^{5}$, their meanings and senses. It is important to notice, in the specific case of this interaction, that there is an entirely favorable context: time, remuneration, collective snack, quieter rhythm, that is, expressions of respect to professionals. This and much more compose the context of meanings that is appropriated by the subjects. These "details" are generally forgotten, a fact that might be one of the reasons why some well-planned interaction propositions do not have the expected results.

In the next set of scenes, where we intend to reveal, in their plots, interactions that favor the construction of self-respect, we have elected, in addition to the investment in the other and the belief in the other's capacity, the facing of conflicts through dialogue as promoter of such interaction quality.

\subsubsection{Facing of Conflicts: Acting Through Dignity, with Dignity. Self-Evaluation at Issue}

First semester 2002. I find Helena rather nervous with a teacher of the afternoon period, who, according to her, has been showing very inadequate attitudes with students for some time now, which Helena tries to bypass by giving careful "signs". Helena says: "Lately she has been "impossible"'; every day there is an inadequacy either with students, peers or parents." This time the problem occurred at the meeting of HTPC, when she said, in a rough manner, that she would no longer read texts or discuss about new practices, because this was already a part of her and, if students did not learn, it was theirs and the school's fault, which did nothing to discipline them. Helena tells that when she heard that she could not stand it; she made an effort to control herself; she felt her face burning. She managed to say to the teacher: "You have to think if this is what you really want - being a teacher -, because you already said you don't like Portuguese, don't like writing, don't like mathematics, and don't like studying; after all, how can you teach?" The teacher did not answer anything. Helena noticed that the group was surprised by her speech - she did not usually respond to the attacks of that teacher. The atmosphere was awful. Helena says she felt very bad, thinking that she might not have said that and that she did not find strength to continue discussing what she had proposed for that meeting. 
In the following week, Helena tells that the teacher went to her saying she did not know how to work certain contents that she thought were late as regards the estimates for that grade, eventually asking for help. According to her, the teacher was very calm and assumed a humble stance when admitting she needed help. Helena kept asking herself if she had been helping her as she should - "if she needed more help than the others, then I should give her a special assistance; after all, is this not what I tell she should do with the students?"

The episode of the teacher that publicly refuses to discuss her practice or continue to study causes such indignation in Helena that she almost loses her temper. We remind that we are talking about self-respect or dignity and, in Helena's own words, the teacher's attitude gives rise to her indignation. The teacher "attacks" Helena's position as school representative, saying she will not assume the responsibility - which is of the coordinator. As teacher, she already does her part and may discharge her responsibility for the problem. It should be noticed that, with a different content, but in a similar way, this same teacher has already voiced herself at another meeting - a scene that we already reviewed. Helena, in face of the teacher's "attack", similarly to the previous episode, feels ashamed: "my face burned" - however, it seems that the quality of shame is different. At the previous episode (scene presented at the beginning of this paper), it was retrospective shame resulting from the failure of her good image. But in this act that we now analyze, it seems that it is prospective shame, because, according to the same author, the feeling of shame modifies the behavior or conduct of the one who experiences it. In the first episode, Helena is "paralyzed"; she is not even able to answer to the teacher's "speech". Here, on the other hand, it seems that the fear of feeling shame makes her burn, and is a motivation for the courage to express what she says to the teacher: "You have to think if this is what you really want - being a teacher -, because you already said you don't like Portuguese, don't like writing, don't like mathematics, don't like studying; after all, how can you teach?"

Helena explains the values of being a teacher and questions the teacher in face of the judges of both - her own and the teacher's. The teacher silences; is it a sign that she does not have answers to Helena's questions? The surprise of the other teachers, noticed by Helena, does not reveal that her image has fallen before the eyes of her judges; on the opposite, new positive values are linked to the "I", because she answers for her honor and with honor to the teacher's criticisms. This is a new component that we could highlight as quality of interaction that favors the construction and maintenance of self-respect, overall when this is about addressing conflicts: it is necessary to act through dignity and with dignity.

About the feeling of respect, Le Doeuff says: "a man who beats his wife not only does not respect her, but as it is evident, is a man who does not respect himself.[7] According to the author, the statement confirms his thesis that "self-respect is a necessary condition to morally respect the other". The teacher morally disrespects Helena, since she attacks values of the order of being. Thus, we could ask ourselves: does she respect herself? The respect for the other is a value present in her identity, understood as the set of representations of herself? It is possible that yes, but not as a core value, because according to La Taille (2002) himself moral values may occupy different places in the identity and, depending on such place, we will have different conducts, namely: when the moral values are present and are at the center of the self representations, we may say that it is the most favorable case for moral acting and thinking - "person of exemplary ethical life" (p.170); when the moral values are present, but are found on the margin of " $\mathrm{I}$ ", the situation is less favorable to moral acting and thinking, because there are values that prevail over them.

The fact is that in this case the interaction favored the maintenance of self-respect, insofar it made the teacher, in face of Helena's questioning, turn to herself to evaluate herself as teacher.

There is no doubt that Helena acts for honor in this episode. The doubt remains as regards the manner: could you say she acted with honor? Let us think about the teacher irrespective of the inadequacy of her actions, what would she have felt? Even if we did not consider her feelings, the fact is that Helena "judges her conduct as reproachable in front of her peers". Thus, it is not surprising that Helena continues bothered with the attitude she had, even after the episode.

Based on this analysis, it may be said that the interactions that favor the construction and maintenance of self-respect lead the involved persons to evaluate their conducts, to turn towards themselves, to what they "are" and not to what they appear to be. This movement is also the one made by Helena when she questions herself about her conducts with the teacher: "would she have given her the attention she needs?", in other words, is she being consistent with the values she praises? Finally, questionings about "being" - starting from what each one is - seem to favor self-respect, exactly because they cause self-judgment by creating inter-subjective spaces where participants are legitimate judges, and, at the same time, they are subject to the judgment of others.

In the characteristic complexity of interactions within the school space, there are interactions that favor self-respect, besides others that do not. Of course that in the scenes that we have just analyzed there are, within the block "does favor", interactions that we could characterize as not promoting self-respect. The same happens with the next set of scenes, where we identify interactions that do not favor the construction of self-respect. The criteria for grouping blocks (following scenes and acts) were some conduct characteristics that are common to each, such as:indifferenc e and lack of commitment, provocations and confrontations, and blaming the other.

\subsection{Interactions that do Not Promote Construction and Maintenance of Self-Respect}

\subsubsection{Indifference and Omission}


I am at a meeting with Helena when Telma knocks at the door and comes in saying that the $4^{\text {th }}$ grade teacher was calling Helena to solve an issue with João, because she couldn't stand him in the class anymore. Helena asks Telma what is going on with the group, because there are multiple complaints about that teacher. Telma answers: "You know what, Helena, we can't stand this teacher anymore. She is getting worse day after day; she humiliates us, pretending she doesn't hear our complaints. It seems we are nothing to her; we are nobody." Helena says that now it is not possible; it is not possible to replace the teacher and that they have to be patient. She asks Telma to talk to the class, because her peers use to listen to her and that she should sent João to her office. Telma apologizes for the wrong attitudes she had in class and leaves. Some minutes later, João comes in. He is crying and seems very nervous: "there're a lot of thieves here in this school." Helena reproaches him, asking him to tell what happened and saying he cannot talk like that. "Yesterday they stole my case inside my backpack. I told the teacher and she didn't do anything (he cried while he talked). Today they stole my pen. I told the teacher again and she didn't do anything. Then I became nervous and cursed." Helena tells him he cannot curse the teacher, whereupon he replies: "but she can pretend she doesn't listen when I need help; then she might not hear the curse as well!" Helena insists saying that he must respect older people and that the classroom is not a place for fighting or cursing. She asks for his diary to send a note to his mother and he cries even more, saying: "please, don't send the note because she will beat me; I promise I won't do that anymore!" Helena says okay, but she wants him to promise he will behave better. He agrees and says he will wait until the time to leave at the corridor, because the teacher said that today she doesn't want him in the class anymore. When he leaves, Helena says that their teacher is "unbearable", and that she doesn't know what to do with her. She already talked to her, but it seems worthless. She would like her to leave the school, but she cannot do anything but wait until the yearend and propose her exit, still running the risk of her staying.

Let us focus on Telma, an eleven-year old child whose mother works as a maid in the neighborhoods of the school. She, together with her younger sister, remains in the school in the morning and in a Youth Center of a nearby church in the afternoon. In this episode, Telma is the bearer of the teacher's message: "she can't stand João in the class anymore" and, answering to Helena's questions, she says: "we can't stand this teacher anymore. She is getting worse day after day; she humiliates us, pretending she doesn't hear our complaints. It seems we are nothing to her; we are nobody."

Considering that Telma's statement corresponds to the truth - what we could verify by observing the conduct of that teacher on many occasions, besides the coordinator's opinion, which we presented in this scene, there are two aspects in Telma's speech we want to analyze: the first aspect concerns the characteristics of the humiliation, and the second addresses the result of the humiliation, as the quality of interaction between the teacher and the students, in case, children between 10 and 12 years. We should further consider the interaction with Helena, who eventually mentions the impossibility of acting - "replacing the teacher" - and placing the solution in the children's "hands" - "being patient" (even if the teacher is not?).

The humiliation is characterized in three categories: the domesticated one (which would be equivalent to mockeries and jokes made between people, which, although being an aggression, are bearable by the manner and period of time they are practiced); the ritualized one (which would be equivalent to degrading someone at specific events - hazing, for instance -, where force is used and exceeds the limit of bearable) and, finally, the victimizing one, which "expresses the intent of degrading people or groups and keeping them, if possible for ever, in the humble position reserved for them".[7] (p.245).

It seems that this last category - the victimizing one - is which characterizes the relationship of this teacher with her students. And, in this case, since this teacher holds the place of authority, there is also the "coercion" component, which grants more strength to the acts aimed at degrading her students. The interesting is that, in Telma's speech, we notice reference not only to the teacher's speech (can't stand João anymore), but, and mainly, according to the girl's evaluation, the conducts reveal her indifference and/or omission silence, refusal to listen and "pretending" that nothing is happening.

In his research on the genesis of the feeling of shame, La Taille[7] finds out that children between 9 and 12 years condemn humiliation. It seems that this is confirmed by Telma, as well as João, as we will see later. Worrisome here is that it is possible that many children that are punished (and we understand the indifference, in this case, as a form of punishment) suffer humiliation without teachers or parents noticing it.

It seems relevant to consider one of the relations between humiliation and shame, overall when dealing with the observations we have made at school. The fact of being repeatedly humiliated may cause victims to start accepting that they are inferior, thus changing the judgment they have about themselves, their good image 6 . This is the risk we run when we do not invest in reflection about moral education with teachers generally, in the sense of turning the school into a space that promotes the construction of negative images by the children, who would start seeing themselves as incapable. Telma says that "she can't stand it anymore" and we will have the opportunity to find her again in another scene of this block when we discuss the values present in her identity.

From the standpoint of the Socio-historical Psychology, we know that the subject is made in and through interaction by the internalization of the context of significations, the measurement of which is made by the other who is also internalized. Within this context of meanings, there are speeches, gestures, attitudes, feelings, emotions and a number of other non-translated affections and aspects. 
Therefore the perception of indifference as humiliation. How is it possible, thus, to internalize respect for yourself and for the other within a context that has interactions of such nature? It seems that the case here is not to show the reason why the interaction does not favor self-respect, but draw attention to why it may favor, as it will be seen later.

We found another relevant aspect as regards interactions that do not favor self-respect in the contents of João's anger, which makes his act of indiscipline legitimate: "there are cases where indiscipline may have ethical reasons[...] when transgression claims for justice.”[6] Well, what is the reason for João cursing (it is not known whether he cursed the teacher or simply said a bad word)? He felt he has been unfairly treated; he was denied the legitimate right to property, due to the impossibility of repossessing his asset. Would he not be entitled to claim for his rights? And the teacher, what is her duty with respect to maintaining the rights of children that are under her responsibility? What can we expect these children to internalize as regards respect for the other and as regards respect for themselves within a context where "theft" is treated with indifference?

João is afraid of his mother, which shows that she invests in values of how "to behave well" in school, or at least "not getting into troubles." However, the mother does also apply expiatory sanctions - the same way as the school does. We will find João in another scene and discuss a little more about his values. For now, we believe we may say that indifference and lack of commitment make it unviable to build positive values, and trigger a series of feelings painful to all those who experience it.

The last aspect we have chosen to address as characteristic of interactions that do not favor the construction and maintenance of self-respect is guilt. This element - guilt - is very present at school, but not as a moral feeling expressed by its actors, but by its contrary - responsibility is not assumed but thrown at others, what justifies the insertion of the following scenes in the block of interactions that do not favor self-respect.

\subsubsection{Guilt and Punishment}

I arrive at school; Helena is not in the room. An employee says she is at the yard and asked me to go there when I arrived. I find here talking to five $4^{\text {th }}$ grade students - Telma, the girl who is the group leader; João, who frequently gets involved in fights, mainly with the teacher; Carlos, who also spends a lot of time at Helena's office, because the teacher often tells him to leave the classroom claiming disrespect; Luís, a twelve-year old boy, the oldest of the group, who divides the class leadership with Telma and Sérgio, an agitated boy who completes the "trouble quintet" of the $4^{\text {th }}$ grade, according to the teacher. On that day, the five did not behave well during the break, when Helena gathers all students and teachers to give messages and sing the National Hymn. The students have already returned to their classrooms and these remained to have a talk with Helena. I approach the group, ask whether she wants me to wait in the office, but she asks me to stay. Helena asks about their behavior in the classroom - lately they are only getting into troubles; what is happening? While Helena talks, two pay attention and the others talk, laugh, poke each other. Helena proceeds with her speech, always stopping to draw attention of all of them. They do not listen; Helena barely finishes what she is saying and they reply, accusing the teacher, accusing the colleagues. At no moment do they take into account the criticisms made by Helena. To them, they are right, it is the teacher that is boring, the coordinator also, and the school is a "mess", because it does not have toilet paper in bathrooms, which, adding to that, are broken. They cannot utter a word in the class and the teacher immediately attacks. They consider themselves disrespected by the teacher and that is why they disrespect her too.

Helena stops talking about the classroom and asks about their behavior at the hymn time: "How difficult would it be to stand quiet, with the hand on your chest in sign of respect for five minutes?"

They defend themselves again: "That guy keeps making fun; I was quiet and the guy kicked me; I was already willing to come, and the teacher grabbed me by the arm; then I got angry and didn't go". Helena asks if they find it right what they have done, and they say yes. Helena still tries, calling them to their responsibility, saying they are the oldest at school and, thus, role models for the younger ones; she asks them, please, not to do that again. Then she stops, asks them to go back to their classrooms; some resist, take time and eventually they obey. I go to the staffroom, and, in front of the closed door there are many students. All of them are talking at the same time and asking for Helena. An employee is with the group, bringing by the hand a child that cries a lot and walks with difficulty. I ask what happened and she says the boy was kicked in the stomach. Two teachers approach, attracted by the noise, and want to know what happened. An employee repeats the story. One of the teachers asks who did that and she points to another boy that is leaning on the wall, with his head down. She goes to him - the aggressor, according to the employee - and says in a much altered tone: "Are you a horse to kick? Don't you know that's where the kidneys are? If you want to kick, go somewhere else, and not to the school. Now you will be sitting there until the end of the break." The boy remains quiet and shrinks even more he seems to be afraid. In the meantime, the teacher of the injured boy tells him to go to the office and put ice on the bruise (there is a purple bruise on the spot). I stay away and keep watching. The teachers return to the staffroom. I approach the boy and ask what happened. Rather nervous he says: "every day that boy messes with me, calls me a "little flower". I already told him to stop because I don't like that. Today he called me again in front of the girls and said my sneakers have "little flowers". I couldn't stand that and kicked him. But I didn't want to hurt him." The boy's teacher approaches and invites him to go back to the class. He follows her.

The two scenes have elements that allow identifying the place of guilt at school. Let us start by the first one. 
We find in this scene some of the already known characters: Telma and João, students and, by their references, the $4^{\text {th }}$ grade teacher, besides Helena. Helena's conversation is focused on respect - this is what she uses as interaction content. It happens that respect is not centered on the being, that is, causing children to think about what students they are, but in the actions they practice - "they only get into troubles." As a matter of fact, the very reason for the conversation results from actions they practiced during a collective activity. Besides continuing to act in a "disrespectful" manner, the students refuse to evaluate their actions, blame the colleagues, the school, the teacher and the coordinator - they "accuse". João says he is disrespectful because he is disrespected - again the blame is put out of the self, on the other, while, from the interaction standpoint, his speech is justified. The same occurs when they are asked about the "hymn time" - "it wasn"t me, it was that guy," and they answer they find what they did was right.

La Taille is based on Lótman[8] to postulate shame as social, overall in the relationship the author makes between fear and shame from the standpoint of culture. $\mathrm{He}$ understands that there is a culture of "we" mediated by shame, and a culture of "they" regulated by fear, that is, the question is the quality of the social relationship: "the nature of the limitations imposed on "we" and "they" is deeply distinct" (1981, p.237). In the cultural "we" the rules of shame and honor would govern. For instance, a person behaves in a certain way - honored - because he is linked to a community that praises these values, which the person does also praise. The community is his judge and his evaluations are his self-respect. Fear and coercion, on their turn, define the relationships of the person with others, insofar he does not see himself as belonging to that community as regards the values he praises.

In the episodes we have analyzed, we found and example of this culture of "they" as in[8]: while students belong to the school community, they do not share the same values that this community "says" it praises, which is now represented by Helena. We point out "says" because we have reasons to believe that while there is an entirely moral speech circulating in the school, the actions they trigger inside the school show to be usually inconsistent with this speech. Thus, the limits of "we" are not the limits of "they"; the community is not legitimized as "judge" of the children, who say they are right in what they do. "They", for the children, is everything that is outside them, everything they are not - "boring", "wrong", a "mess". This culture of "they" that we characterize is mediated by fear and indifference (it does not concern me) and it forms the contents of interaction.

That is why we do not find the feeling of shame - first because it seems to us that the value "respecting" the other is not in the core of the self representations for Telma, João and the three other boys. Would we be able to state that? Telma, in another situation we already analyzed, seems to respect the coordinator. She is also respected by the group, which grants her a leadership position. But is it because of her moral or non-moral values? For the self-respect or self-esteem? We believe it is for the latter. João, also in another situation, claims for his rights, and, in the present scene, says he is not respected and so he disrespects. Would these values be present, but at the margin of "I", and thus, would there be other values of higher precedence that eventually subjugate the former ones? Or does the shame not emerge because the "judge" (coordinator) is not legitimate? It seems that both the hypotheses are valid.

The answer that the children gave when asked if they found it right to act that way seems to reveal that our first hypothesis is adequate; the values of respecting the other and yourself are present, but at the margin of the set of self representations, and this case is less favorable to the moral acting and thinking.

The core value here concerns the self-esteem, since the children remove all criticisms that befall on their actions, leading us to say that the interactions that are based on the questioning of actions (what has been done) do not favor the construction of self-respect, because they do not give rise to the self-evaluation of being. In the same way, as we see in the scene, even when questioning the actions, this interaction does not trigger the feeling of guilt, indicating that there is no sharing of common referential perspectives that could establish the dialogue that works in the inter-subjective space. These references, in this case, concern values, and it is possible to notice how the coordinator, while making efforts to install the dialogue, remains in the same referential perspective, which differs from that of students - "they are wrong" "we are right" (culture of "they"); she has her reasons and they have theirs, or still, the motivational strength for the moral acting and thinking are distinct.

The second scene reports a fact that involves coercion and fear, besides humiliation suffered by the aggressor boy. However, what does interest us here is the quality of interaction, very common as a means of conducting facts of this nature at school. In face of an aggression, either moral or physical or physical and moral, the aggressor is usually vehemently reproached; the victim is accepted and no movements are made to discuss the reasons or understand the causes of the conflict. One seems to forget that aggressions do usually not occur without a reason. This type of interaction, which has as its content the coercion and expiatory sanction, eventually creates a culture at school of "command-fear-obedience"7, which has dramatic consequences for interpersonal relationships because no one manages, at least nowadays, to exercise the "command" permanently, and since children do only "stop" in face of the command, the limits are eventually broadened.

As a consequence, heteronomy results as the only possible manner of the inter-subjective working, and this is the context of signification that is internalized by children and adults involved directly in the conflicts and/or by those who live with these situations. Therefore, the expressions "it's useless" to call the parents "it's useless to talk/speak" are frequently speeches that refer to the attitudes of students and/or teachers, or even of the teaching system. 
The "disrespect" is, undoubtedly, the content of interactions present in our scene - disrespect to the physical integrity (in case of the students) and moral disrespect (in the teacher's intervention). But, where is the place of guilt within these situations? It is outside the subject, it is always of the other. And the feeling of guilt is always moral; our observations confirm the absence of moral conducts in many of the interactions that take place in the school space, exactly for the absence of moral feelings. It seems that the culture of "they" has been assuming the primary characteristic of these interactions.

The constant complaints and the search to find who is guilty for problems that concur with pedagogical actions are interaction contents, which sometimes dominate spaces of permanent education or conversations and exchanges in the everyday life of the school. They do not favor the construction and maintenance of self-respect, insofar the subjects that relate to each other publicly "deny their responsibility" for problems that exist inside the school.

If, from the standpoint of teaching-learning of academic contents we often find the "self-acquittal" movement by teachers and school, we think that in case of the moral education, which is culturally considered as the family's responsibility, "escaping" from the responsibility, or better saying, from the duty, is even greater.

With respect to this meaning, in our research we found that the place of the assigned guilt alternates: it is sometimes laid on students, others on the "indiscipline" (which at school seems to have reached the status of proper noun), sometimes on the school, sometimes on the coordinator. But never on your own.

\section{Conclusions}

Our purpose was to identify values present at school and verify which interactions promote their construction and/or maintenance, and, in case of self-respect, the moral values. Our hypothesis was that if disrespect exists and persists at school it is because the interactions somehow favor its maintenance.

\subsection{The Place of Respect in School}

At the beginning, we submitted the following questions: if it is true that disrespect is a fact at school, what are the reasons for its maintenance? Which interaction qualities in school do either favor or not the maintenance and/or construction of self-respect?

Some results of our study show that respect is present at school as a value for its actors. It appears in the actions and conducts of the coordinator, of teachers and students, and also as an ideal of conduct, mainly of teachers and the coordinator. It happens that we found this respect as value, occupying different places in the set of representations that these school actors have of themselves: sometimes they are on the margin of "I" and, in this case, the respect is valid only for the other and not for yourself, which does not configure it as moral or as self-respect, and sometimes, less often, as self-respect, occupying the core of the set of self representations. However, what we notice is that its counterparty, disrespect, is a reality at school, and we believe that the reason for its maintenance lies exactly on the quality of the interactions.

We saw that interactions that have as their characteristics the indifference and lack of commitment, provocations and confrontation, and still, the blaming thrown on others, not only do not favor the construction and maintenance of self-respect, but, on the opposite, favor the construction and maintenance of disrespect, as some students state: "he cursed me, I kicked"; "she pretended she didn't listen, I cursed." This occurs because interactions with these qualities wake up feelings that depreciate the being before the eyes of others, such as humiliation, for instance.

In these interactions there is also the expiatory sanction, which is incidental on the action that is practiced, with the purpose of making the individual "pay" for what he did.[7] Well, if after "kicking" the colleague you are reprimanded and remain "seated in the corridor during the break", you pay for what you did and the moral debt is discharged. Once the punishment is borne, the "student" is in good standing with the community and the "guilt" for the action practiced should not remain - he is "purified" by expiation. When we ask any student: what happens with someone who behaves badly at school, he answers: "He is reprimanded, misses the break time, talks to the coordinator, talks to the principal, takes a note to the mother, is beaten by the mother," and this is the generalization resulting from the internalization process of this interactive context.

Being worthy of respect is not a result of a potential that the context awakes, but of the progressive participation of the individual in social practices that have respect as moral value. It is there that he transforms as his own not only the values preserved by the society, but also the ways of thinking and acting on and with these values. With this presupposition of Socio-historical Psychology, we may say that, between the value in itself and the value for itself, the value for others interposes. Thus, the meaning of value for the child was first translated by others within his relationships. Well, self-respect implies necessarily the respect for the other. If the value for me is only a value because it previously was/is a value for the other, then wouldn't the values that are not present in me (the respect required by the school) be also absent in others around me, and, in the same way, wasn't/isn't the value that is present in me and that the school abominates (disrespect) previously present in others (including the school)?

The human development is based on the plan of interactions, when the subject makes as his own an action or thought that initially has a shared meaning. This intra-subjective plan, with genesis in the inter-subjective plan, is a way of functioning that is created with the internalization, where the source of regulation is displaced to the subject himself and, far from being a copy of the outside plan, the internal functioning results from an appropriation 
of forms of thought and action that is dependent on both strategies and knowledge dominated by the subject and occurrences within the interactive context.[2]

This is equivalent to saying that the construction and maintenance of self-respect in school depend on both experiences and feelings of children with regard to what it means to respect the other and yourself, and on the quality of interactions of which they take part in school. Thus, knowing what children think about moral and immoral actions, such as lying, attacking, humiliating, disrespecting and about their counterparties, i.e., telling the truth, tolerating and respecting is essential in interactions aimed at the construction and/or maintenance of self respect.

We saw these interactions in school, when there was, on part of the educator, the investment in/from the other, the belief in the capacity, a priori, the welcoming and care for the other. This because investing in the other, in his good qualities, is equivalent to offering self-respect; thus, self-respect is the content of interaction as regards moral values, which should be appropriated by the subjects in a relationship. It happens that we often idealize this movement as harmonious and uniform, what is not possible, exactly because it involves subjectivities that are related to each other. Therefore, as it was seen, in an interactive process it is not enough to invest and welcome; care must be taken with the other, with that of the other, that is, with what you do with the "welcomed".

Building self-respect implies evaluating yourself, examining values and beliefs, and if it is true that there is a permanent search by the individual for associating positive values with "I", we imagine that if we engage in a self-judgment, from the consideration of our qualities, that may explain the movement we observe. In addition, the fact that self-respect is essentially within the scope of moral makes us consider the constitution of the ethical subject, which we will address with a view to concluding this article.

Moral refers to laws that regulate the human conducts, while ethics corresponds to "ideals" that give meaning to life. Thus, while moral tries to provide answers to the question "how should I act?" - dictating actions of the individual that are related to rules permeated with values, the ethics tries to respond the question "how to live?", relating thus to the ideal of life, to what the individual wishes to be; his project of future, that is also, of course, based on values.[4]

This set of scenes reveals that there are many good things happening at school, with ethical commitment that favors not only the construction of moral values but the ethical education and the exercise of citizenship. We believe it is important to draw attention to this fact, because by working with the everyday life scenes, the complexity of relationships and interactions that characterize how the school works stands out, where persons with different values and, thus, different images or self representations coexist. This heterogeneity, which is not considered in many researches and/or theories, or even in propositions of pedagogical practices or permanent education programs, leads us to develop fragmented views of the educative processes, and sometimes we even rank them as bad or good, positive or negative, successful or unsuccessful, exactly because we have lost the possibility of conceiving the entirety, that is, the very process and the network of relationships and interactions that form it. This finding leads us to state that there are implied and ethical conscious thoughts, studies, practices and actions at school, competing with others that are often immoral. As regards self-respect, in case of pedagogical propositions, we should invest in the first ones.

If we actually wish, through school education, to educate ethical subjects, it seems legitimate to say that it is necessary to invest in moral education, starting from the training of teachers and reflection on the interactions that enable the construction/maintenance of values for the constitution of a more worthy and honored life of subjects that inhabit the school space. We understand that, from the perspective of self-respect, the answer to the question "what am I" will lead to the answer to the questions "what do I want to be"

\section{REFERENCES}

[1] DAVIS, C. et al. Papel e valor das interações em sala de aula. Cadernos de Pesquisa, São Paulo, n. 71, p.49-54, nov. 1989.[ [Links ]

[2] GÓES, M. C. A Natureza social do desenvolvimento psicológico. Caderno Cedes, Campinas, n. 24, p.21-28, 1991.[ Links ]

[3] A Formação do indivíduo nas relações sociais: contribuições teóricas de Lev S. Vigotski e Pierre Janet. Educação \& Sociedade, Campinas, n. 71, p.116-131, 2000.[ Links ]

[4] HARKOT-DE-LA-TAILLE, E. Ensaio semiótico sobre a vergonha. São Paulo: Humanitas, FFLCH/USP, 1999.[ [Links ]

[5] LA TAILlE, Y. de. Grandes pensadores em educação: o desafio da aprendizagem da formação moral e da avaliação. Porto Alegre: Mediação, 2001. A Questão da indisciplina: ética, virtudes e educação, p.67-97.[ Links ]

[6] Limites: três dimensões educacionais. São Paulo: Ática, 1998.[ [Links ]

[7] Vergonha, a ferida moral. Petrópolis: Rio de Janeiro, Vozes, 2002.[ [inks ]

[8] LÓTMAN, I. M. Semiótica dos conceitos de vergonha e medo. In: LÓTMAN, I. M. et al. (org.). Ensaios de semiótica soviética. Lisboa: Horizonte, 1981. p.237-240.[ Links ]

[9] PARO, V. Por dentro da escola pública. São Paulo: Xamã, 1995.[ [Links ]

[10] PIAGET, J. O Juízo moral na criança. 3. ed. São Paulo: Summus, 1994.[ Links ]

[11] PINO, A. O Conceito de mediação semiótica em Vigotski e seu papel na explicação do psiquismo humano. Cadernos CEDES, Campinas, n.24, p.38-51, 1991.[ Links ]

[12] O Biológico e o cultural nos processos cognitivos. In: MORTIMER, E. F.; SMOLKA, A. L. (orgs.). Linguagem, 
cultura e cognição. Belo Horizonte: Autêntica, 2001. p.21-50.[ Links ]

[13] SOUZA, V. L. T. de. As Interações na escola e seus significados e sentidos na construção de valores: um estudo sobre o cotidiano escolar. São Paulo, 2004. Tese (dout.) Programa de Estudos Pós-Graduados em Psicologia da Educação da PUC-SP.[ Links ]
[14] VIGOTSKI, L. S. Formação social da mente. São Paulo: Martins Fontes, 1987.[ Links ]

[15] Manuscrito de 1929. Educação \& Sociedade, Campinas, n.71, p.21-44, 2000.[ Links ]

[16] The text presents some of the doctorate research results (Souza, 2004). 